rał jako polemiki z nieprzyjaznym nastawieniem do Galliena wielkiego niemieckiego uczonego. Od szeregu lat pełniejsze poznanie czasów Galliena i jego samego wniosło więcej odcieni do portretu Galliena, już nie tylko czarnego, jaki wyłania się z opisów niechętnych cesarzowi danych autorów, i białego, jaki konstruowany był na bieżąco w panegyricznych hasłach epigraficznych i numizmatycznych. Sam M. Geiger unika skrajnych osądów i ocenia Galliena w sposób nader wyważony.

Ta „poprawność” jest cechą najbardziej wyróżniającą opracowanie. Nie ma tu też miejsca na odkrywcze sądy, śmiałe hipotezy i kontrowersyjne teorie. Jest natomiast wartościowe zestawienie źródeł i stanu badań, a także syntetyczne ujęcie dziejów panowania Galliena.

Agata A. Kluczek

\title{
Między prestiżem a politycznym marginesem
}

\author{
Between prestige and political margin
}

(c) $(1) \Theta$

http://dx.doi.org/10.12775/KLIO.2015.052

ednym z wielu powodów niedostatków w badaniach nad różnorodny-
mi aspektami dziejów magnaterii i szlachty polskiej w okresie wczesno-
nowożytnym jest bez wątpienia stan zachowania bazy źródłowej. Jak już

* A. Perłakowski, Kariera i upadek królewskiego faworyta. Aleksander Józef Sutkowski $w$ latach 1695-1738, Towarzystwo Wydawnicze „Historia Iagellonica”, Kraków 2013, ss. 327, ISBN: 978-83-6226-158-1. 
niejednokrotnie podkreślano w literaturze historycznej, w wyniku zawieruch dziejowych, w szczególności zaś drugiej wojny światowej, bezpowrotnie zostały utracone liczne materiały źródłowe, które mogłyby uzupełnić naszą aktualną wiedzę na temat życia i działalności przedstawicieli stanu szlacheckiego. Stwierdzenie to odnosi się zwłaszcza do podstawowych zespołów źródłowych do badań nad szlachtą poszczególnych prowincji, województw oraz ziem Rzeczypospolitej - archiwów rodowych ${ }^{1}$. Niemniej jednak wszyscy badacze zajmujący się karierami poszczególnych przedstawicieli stanu szlacheckiego są zgodni, że tego typu badania, pomimo pewnych braków źródłowych, powinny być kontynuowane. Dlatego też cieszy, że postać kontrowersyjnego „karierowicza” czasów saskich, Aleksandra Józefa Sułkowskiego, znalazła swojego biografa. Autorem omawianej pracy jest Adam Perłakowski z Instytutu Historii Uniwersytetu Jagiellońskiego w Krakowie. Niewątpliwie badacz ten, jako reprezentant młodszego pokolenia historyków, okazuje się w świetle dotychczasowej twórczości badawczej bardzo dobrym specjalistą o szerokich zainteresowaniach naukowych. Interesują go przede wszystkim kwestie kontaktów dworu drezdeńskiego z Rzeczpospolitą, dzieje unii polsko-saskiej czy problemy gospodarcze tych państw w pierwszej połowie XVIII wieku. Dowodem tego są liczne publikacje książkowe oraz edycje źródeł. Autor ma na swoim koncie m.in. biografię Jana Jerzego Przebendowskiego ${ }^{2}$ czy opublikowanie listów tego magnata ${ }^{3}$.

Aleksander Józef Sułkowski jest przykładem osoby, która praktycznie sama sobie może zawdzięczać, nie licząc oczywiście poparcia królewskiego, wprowadzenie swojej osoby do grona najbardziej wpływowych osób osiemnastowiecznej Rzeczypospolitej i Saksonii. Nasuwa się tu pewne po-

${ }^{1}$ Problem ten był poruszany przez wielu historyków i archiwistów zajmujących się tematyką rodów szlacheckich, zob. m.in. W. Nowosad, Archiwa szlachty Prus Królewskich, Toruń 2005.

${ }^{2}$ A. Perłakowski, Jan Jerzy Przebendowski podskarbi wielki koronny i dobrodziej ostrowski. Szkic biograficzny, Kraków 2014.

${ }^{3}$ Listy Jana Jerzego Przebendowskiego podskarbiego wielkiego koronnego do Adama Mikotaja Sieniawskiego wojewody betskiego i hetmana wielkiego koronnego z lat 1704-1725. „Interes WM Pana wspomniatem Królowi Jmci...”, wyd. i oprac. A. Perłakowski, Kraków 2007. 
dobieństwo do wspomnianego wcześniej Jana Jerzego Przebendowskiego, podskarbiego wielkiego koronnego, który był twórcą potęgi rodu Przebendowskich ${ }^{4}$. Powracając jednak do Sułkowskiego, należy cieszyć się, że to właśnie ta osoba doczekała się szczegółowej analizy monograficznej. Jest to bardzo ważne dla badań nad dziejami politycznymi epoki saskiej, chociażby ze względu na fak, że Aleksander Józef Sułkowski znajdował się w najbliższym otoczeniu dworu królewskiego, odgrywając w tych kręgach niebagatelną rolę. $Z$ całą pewnością warto prowadzić dalsze badania o charakterze biograficznym w stosunku do innych osób z najbliższego otoczenia władców, np. dyplomatów, którzy mieli niewątpliwie duży wpływ na przebieg wielu wydarzeń politycznych w omawianym okresie. Badania, które w ostatnim czasie prowadzi Adam Perłakowski, należy uznać za jak najbardziej uzasadnione i potrzebne. Przede wszystkim trzeba żywić nadzieję, że tego typu inicjatywy badawcze nadal będą się cieszyły zainteresowaniem historyków, co pozwoli w dalszym ciagu odtwarzać niezwykle zawiłe życie polityczne, społeczne i kulturowe osiemnastowiecznej Rzeczypospolitej.

Nie ulega wątpliwości, że przedstawienie życiorysu A. J. Sułkowskiego, chociaż niepełnego, bo nieomawiającego ostatnich lat jego życia, było zadaniem niezwykle trudnym. Na fakt ten składało się wiele czynników, jak chociażby II wojna światowa, która niestety skutecznie przyczyniła się do zniszczenia wielu ciekawych materiałów źródłowych, w tym Archiwum Książąt Sułkowskich.

Biografia poświęcona Sułkowskiemu jest niewątpliwie pracą, która zasługuje na uwagę. Liczy 327 stron i została podzielona na pięć części, a te z kolei na mniejsze podrozdziały. Oczywiście w pracy znalazł się także mocno rozwinięty wstęp, uwagi końcowe, aneks oraz obszerna bibliografia.

Pierwsza część książki (Pierwsze kroki w polityce) poświęcona jest pierwszym etapom kariery Sułkowskiego. To niezwykle ciekawa część monografii, która omawia wszelkie niejasności powstałe wokół daty urodzin bohatera oraz wokół ojca Sułkowskiego. Sam autor zauważa małe prawdopodobieństwo, by Sułkowski był synem króla Fryderyka Augusta I, który mógł mieć romans z Elżbietą z Wagrowskich primo voto Szalewską. Tego typu plotek niepotrzebnie namnożyło się w literaturze historycznej. Jednak

${ }^{4}$ A. Perłakowski, Jan Jerzy Przebendowski... 
dzięki ustaleniom Adama Perłakowskiego podważone zostały tu m.in. prace Ryszarda Kincla ${ }^{5}$ i Marii Dernałowicz 6 , którzy opowiadali się za królewskim ojcostwem. Na niniejsze poglądy wspomnianych autorów mogła wpłynąć błyskawiczna kariera u boku króla, jednak bez potwierdzenia źródłowego takie domysły słusznie zostały potraktowane jako nierzetelne i mało realne. Według autora ojcem tego urzędnika był starosta krzeszowicki i burgrabia krakowski Stanisław Sułkowski, który urodził się w połowie XVII wieku. Część pierwsza pracy, pomimo że najkrótsza (liczy 20 stron), stawia kilka istotnych tez, które w dalszej części będą miały zasadnicze znaczenie. Najważniejszą sprawą jest fakt, iż bliskość dworu mogła w niesłychanym szybkim tempie wywindować karierę szlachcica. Nawet zwykłe uczestnictwo w polowaniach stawało się bardzo ważnym elementem $\mathrm{w}$ budowaniu pozycji $\mathrm{w}$ otoczeniu królewskim. Adam Perłakowski zauważył zresztą, że w tego typu „zabawach” uczestniczyli inni ważni i prominentni uczestnicy życia politycznego Saksonii, co owocowało później znajomościami w kręgach arystokratycznych. Drugą rzeczą jest problematyka wojskowa Sułkowskiego. Jest to sprawa bardziej złożona, ponieważ sam Sułkowski nigdy nie stał się pierwszoplanową postacią w jakiejkolwiek wojnie, a uczestniczył w kilku konfliktach w przeciągu swojego życia. Byłoby jednak błędem nieporuszenie tematu jego zdolności militarnych. Co więcej, jego rodzina, zwłaszcza rodzeństwo i potomstwo, wiązało swoją przyszłość z wojskiem. W pracy nie zostało to zaakcentowane, co wynika oczywiście ze ścisłej problematyki podjętej przez autora.

A. J. Sułkowski jest przykładem osoby, która w stosunkowo szybkim czasie uzyskała wiele znaczących godności, stając się przy okazji jedną z najważniejszych osób na dworze królewskim. Taki stan rzeczy był spowodowany obecnością w Dreźnie przy panującej dynastii. Towarzyszył wtedy Sułkowski królewiczowi Fryderykowi Augustowi II jako szambelan, a następnie kamerjunkier ${ }^{7}$. Już wtedy miał okazję przebywać z młodym królewiczem na polowaniach, odgrywał również rolę pośrednika w przekazywaniu poufnej korespondencji pomiędzy Augustem II a jego synem, co

${ }^{5}$ R. Kincel, Ktopotliwy książę Sutkowski, Katowice 1984, s 8.

${ }^{6}$ M. Dernałowicz, Portret Familii, Warszawa 1990, s. 38.

${ }^{7}$ Urząd kamerjunkra był odpowiednikiem polskiego szambelana. 
było dużym zaszczytem. Zaufanie, które zdobył, zaprocentowało w niedalekiej przyszłości. W drugiej połowie lat dwudziestych został wynagrodzony nadaniami ziemskimi nie tylko w Koronie, ale również w Saksonii. Nie wszystkie polskie lub litewskie rody, nawet te zasłużone, doznały takich zaszczytów, co mogło powodować zawiść oraz chęć poznania go. Bardzo dobrym przykładem jest Jan Ansgary Czapski, który chciał wykorzystać Sułkowskiego do wkupienia się w łaski królewskie, co mu się oczywiście udało. Postać ta jest o tyle ciekawa, że stał się jednym z najbogatszych, jeśli nie najbogatszym, magnatem Prus Królewskich. Magnat ten niewątpliwie mógł zawdzięczać swoje awanse i zaszczyty właśnie Sułkowskiemu. Oprócz majątku mógł pochwalić się również błyskotliwą karierą polityczną (był m.in. podskarbim wielkim koronnym). Podobnie jak A. J. Sułkowski był zagorzałym stronnikiem saskim, nawet wtedy gdy Stanisław Leszczyński i jego stronnicy uzyskiwali pewną przewagę w walce o wpływy polityczne na terenie kraju ${ }^{8}$. Relacje Sułkowskiego i Jana Ansgarego w późniejszym okresie ochłodziły się ze względu na to, że ten pierwszy nie reagował na prośby pruskiego magnata odnośnie do przyznania mu innych godności urzędniczych. Nie zmienia to jednak faktu, że obaj magnaci przez długi czas ściśle i skutecznie ze sobą współpracowali. Przykładem jest chociażby przyznanie urzędu wojewody pomorskiemu Jakubowi Florianowi Narzymskiemu, który dzięki staraniom Czapskiego uzyskał tę funkcję po śmierci Piotra Jana Czapskiego.

Inną kwestią, na którą zwrócono tutaj uwagę, było dobre małżeństwo. Sułkowski ożenił się z damą dworu Marii Józefy, Anną Franciszką Katarzyną von Stein und Jettingen, wywodzącą się ze szwajcarskiej rodziny, która osiedliła się w Saksonii. Jeśli chodzi o rodzinę, szkodą dla zainteresowanych tym tematem jest fakt pominięcia przez autora środowiska rodzinnego, z której wywodził się A. J. Sułkowski. Chodzi dokładnie o krótkie scharakteryzowanie karier ojca i dziadka. W mojej ocenie jest to szczególnie ważne, jeśli chodzi o budowanie swojej pozycji i prestiżu, chociażby z tego

${ }^{8} \mathrm{Na}$ pozycję w kręgach Augusta III zwracał uwagę przede wszystkim J. Dygdała, Podskarbi wielki koronny Jan Ansgary Czapski - budowa pozycji spotecznej i prestiżu nowego magnata w pierwszej potowie XVIII wieku, „Zapiski Historyczne” 2005, t. 70, z. 1, s. 27 53. 
względu, że bohater książki musiał odziedziczyć pewne dobra, od których mógł zacząć budowę własnego majątku. Przedstawienie środowiska rodzinnego jest również ważne dlatego, że młody magnat musiał skądś czerpać pewne wzorce. Zresztą nie powinno być błędem, że to właśnie najbliższe, rodzinne otoczenie mogło determinować wiele zachować młodego i ambitnego szlachcica. Warto byłoby w przyszłości poświęcić kilka słów na temat poszczególnych linii rodu Sułkowskich, których potęga przypada na czasy saskie i stanisławowskie. Notabene w okresie napoleońskim, głównie dzięki wojsku, potrafili także utrzymać duże znaczenie na arenie politycznej. O potrzebie badań nad monografią omawiającą losy tego rodu wspomina Henryk Palkij, który uważa, że Sułkowscy byli przed czasami Aleksandra Józefa mało znani ${ }^{9}$, choć jak sam autor podkreśla:

postulat podjęcia bardziej szczegółowych studiów nad dziejami tego rodu, chociażby na podstawę źródłową, nie będzie on łatwy do spełnienia. Jednym z najważniejszych obszarów badania powinno być moim zdaniem pełniejsze określenie miejsca rodu wśród rodów szlacheckich i magnackich Rzeczypospolitej i potem w XIX-wiecznym ziemiaństwie ${ }^{10}$.

Jak widać podjęcie takich studiów w przyszłości nie będzie łatwe, jednak będzie potrzebne.

Bardzo ważnym momentem w życiu Sułkowskiego była śmierć Augusta II, do której doszło 1 II 1733 roku. Okres ten niewątpliwie zaważył na jego dalszej karierze, ponieważ umiejętnie pokierowanie polityki królewskiego syna mogło decydować o zaistnieniu w wielkiej polityce. $\mathrm{Na}$ omówienie tych kwestii została poświęcona część II książki ( $U$ boku elektora saskiego podczas zabiegów o polską koronę). Jak powszechnie wiadomo, obozowi politycznemu związanemu z Augustem II zależało na zapewnieniu kontynuacji panowania dynastii saskiej w Rzeczypospolitej. Dlatego też rozpoczęto zabiegać o stworzenie w Polsce odpowiednio silnego obozu prosaskiego. Rok 1733 tak naprawdę rozpoczął karierę urzędniczą Sułkowskiego na wysokim szczeblu. Przejmował obowiązki marszałka dwo-

${ }^{9}$ H. Palkij, Sutkowscy herbu Sulima, [w:] Sutkowscy - życie i dzieto. Materiaty z sesji naukowej „Sutkowscy-życie i dzieto”, red. Z. Moliński, Rydzyna-Leszno 1999, s. 15.

${ }^{10}$ Ibidem, s. 28. 
ru, by następnie otrzymać urząd tajnego radcy, ale bez prawa głosu. Adam Perłakowski za innymi autorami twierdzi, że na ten fakt wpłynęło jego wyznanie katolickie. W tym samym czasie wpływy na dworze królewskim zdobywał Henryk Brühl, późniejszy oponent Sułkowskiego. Przede wszystkim obaj ministrowie zajmowali się bardzo polityką zagraniczną. Nie będzie jednak błędem stwierdzenie, że zostanie członkiem Tajnego Gabinetu stawiało poszczególne osoby w elicie politycznej kraju. Szczególnie ważne dla Sułkowskiego były wpływy w departamencie spraw wojskowych, chociaż nie była to osoba obdarzona zdolnościami dowódczymi. Jeszcze w drugiej połowie 1733 roku otrzymał od cesarza Karola VI tytuł dziedzicznego hrabiego Świętego Cesarstwa Rzymskiego Narodu Niemieckiego z prawem indygenatu na obszarze Czech i Śląska. Dzięki temu zaszczytowi prestiż ministra nadal się zwiększał. Stał się wtedy jedną z najbardziej znaczących osób w Saksonii dzięki poparciu Fryderyka Augusta II.

Rzeczpospolita stała się polem bitwy pomiędzy obozem saskim a Stanisławem Leszczyńskim, popieranym m.in. przez Francję. Pewnym problemem dla odtworzenia pełnego życiorysu ministra saskiego był brak przekazów źródłowych, które jednoznacznie wskazywałyby na mniejszą lub większą znajomość środowiska politycznego Leszczyńskiego.

W dalszej części książki jest mowa o wydarzeniach z 1734 roku, który upłynął na ostrej walce pomiędzy stronnikami. Będący przy boku monarchy Sułkowski zajmował się sprawami bieżącymi, awansował w tym czasie na urząd generała majora. Jak widać, kariera polityczna szła w parze z wojskową. Uczestniczył zresztą w oblężeniu Gdańska, w którym przebywał Stanisław Leszczyński. Niestety ani autor, ani inni historycy nie mogą jednoznacznie stwierdzić, jaki był jego udział w obleganiu tego miasta. Wiadomo jednak, że był głosem doradczym, jednakże główną rolę odgrywali podczas oblężenia Rosjanie. Ciekawostką jest fakt, że Stanisław Leszczyński uciekł $\mathrm{w}$ przebraniu chłopskim $\mathrm{z}$ obleganego miasta ${ }^{11}$ i to wydarzenie zamykało pewien okres w życiu Sułkowskiego. Nastał czas prób otrzymania majątków po Leszczyńskim, który po pobycie w Kwidzynie i Królewcu udał się do Francji.

${ }^{11}$ Barwnie te wydarzenia opisuje sam król, S. Leszczyński, Opis ucieczki z Gdańska do Kwidzyna, oprac. E. Cieślak, Olsztyn 1988. 
W mojej ocenie najważniejszą częścią pracy jest część trzecia (U szczytu powodzenia), w której zostały poddane ocenie polityczne, a także wojskowe zdolności bohatera książki. Widzimy tutaj Sułkowskiego u królewskiego boku w Warszawie 1734 roku. Wraz z innymi członkami otoczenia króla brał udział w licznych naradach dotyczących m.in. bicia monety czy w mediacjach pomiędzy dawnymi stronnikami Leszczyńskiego a Augustem III. Niewątpliwie okres ten, jak udowodnił zresztą autor, był dla ministra i całego dworu niezwykle pracowity. Zdawał sobie sprawę, że pewne niebezpieczeństwo niosą ze sobą magnaci, którzy udali się na tzw. emigrację królewiecką. Mimo że nie odznaczył się jako dowódca (był od 1734 roku generałem majorem), udało mu się ponownie awansować w hierarchii wojskowej. W 1735 roku został mianowany generałem lejtnantem armii saskiej. W tej części pracy zwrócono również uwagę na powstające paszkwile, które oczerniały Augusta III, jak i jego otoczenie. Suchej nitki nie zostawiono na Sułkowskim, którego określano jako człowieka pełnego pychy, karierowicza i odpowiedzialnego za sprowadzenie do kraju obcych wojsk.

Co ciekawe, minister jeszcze w tym samym roku udał się przez Drezno nad Ren, by śledzić działania zbrojne pomiędzy Francja a Habsburgami. Nie udało mu się jednak odnieść żadnych sukcesów, które spowodowałyby dalsze awanse. Adam Perłakowski zwraca uwagę, słusznie zresztą, że pierwszy minister zaczął coraz większą uwagę poświęcać rzeczom przyziemnym, oddalając swoje zainteresowania od aktualnych wydarzeń politycznych. W mojej ocenie nie do końca zostały wyjaśnione przyczyny tego stanu rzeczy. Być może spowodowane to było charakterem ministra, który słynął ze zbytniej pewności siebie.

Będąc przy problematyce wojskowej faworyta królewskiego, nie można było ominąc tematu jego uczestnictwa w wyprawie wojennej przeciw Turcji w 1737 roku. Podobnie jak w innych kampaniach wojennych, tak również i tu nie osiągnął praktycznie żadnych sukcesów. To właśnie ten czas uważany jest za przełomowy dla kariery Sułkowskiego. Według autora pracy drugi z ministrów - Henryk Brühl - wykorzystał ten okres, by przygotować się do rozprawy z konkurentem. Niestety, teza ta nie została potwierdzona bezpośrednio w korespondencji lub innego rodzaju źródłach.

Część następna (Ptawiąc się w Pańskiej tasce) omawia szczyt potęgi Sułkowskiego. Zostały tutaj opisane jego polityczne koligacje z wieloma 
rodzinami magnackimi. Dużo miejsca Adam Perłakowski poświęcił w tym miejscu rodzinie Czapskim h. Leliwa, z Prus Królewskich, która na początku XVIII wieku weszła do elitarnego grona magnaterii. Będąc przy kwestii powiązań z innymi znaczącymi klikami magnackimi, należy zaznaczyć, że wielu przedstawicieli magnaterii wręcz prosiła Sułkowskiego o względy. W pracy częściowo została poruszona kwestia Konstancji z Gnińskich Czapskiej, która jako żona stronnika Leszczyńskiego prosiła ministra o wstawiennictwo dla jej syna Tomasza w sprawie objęcia urzędu wojewody pomorskiego czy uzyskania Orderu Orła Białego. Bardzo cieszy fakt, iż Adam Perłakowski potwierdził, że śmierć wspomnianego wcześniej wojewody pomorskiego Piotra Jana nastąpiła w 1736 roku, a nie jak twierdzą niektóre prace w 1737 roku $^{12}$. Dowodem na to są listy z grudnia tego roku żony wojewody do A. J. Sułkowskiego, w których używa w stosunku do swojego męża zwrotu „nieboszczyk”.

To co osiągnął ten polityk w tak krótkim czasie, bo w latach 1733-1738, dla innych wydawało się czymś niewyobrażalnym. Jednak jego „upadek” nastąpił gwałtownie i niespodziewanie. Czym było to spowodowane? Otóż przy królu pojawiła się inna i być może bardziej błyskotliwa oraz zdolniejsza osoba, której tak samo zależało na osiągnięciu wpływów. Chodzi dokładnie o wspomnianego wcześniej Henryka Brühla, który krok po kroku rozwijał również swoją karierę. Dzięki szerokiej analizie źródłowej udało się w tej części pracy przedstawić zabiegi o wpływy drugiego z ministrów, co daje czytelnikowi porównanie pomiędzy oboma politykami. Adam Perłakowski przedstawił tutaj Brühla również jako osobę niezwykle ambitną, ale też i chciwą. Z drugiej jednak strony w omawianej książce zobaczymy Sułkowskiego jako osobę lekceważącą przeciwników politycznych, uważając ich za gorszych od siebie i nie tak zdolnych jak on sam. Myślę, że należy się zgodzić z autorem niniejszej rozprawy, że Sułkowski nie był mężem stanu ani osobą, która posiadała instynkt polityczny, pozwalający mu się zapisać mocniej na kartach historii. Co więcej, Henryk Brühl okazał się człowiekiem o wiele bardziej sprytnym i wyrachowanym. Świadczy o tym wpajanie Augustowi swoich pomysłów i uczuć, wmawiając

12 S. Achremczyk, Jan Piotr h. Leliwa, [w:] Stownik Biograficzny Pomorza Nadwiślańskiego, t. 1: A-F, red. S. Gierszewski, Gdańsk 1993, s. 255. 
innym przy okazji, że król jest całkowicie samodzielny. Już po „upadku” Sułkowskiego okazało się, że jego następca sprzeniewierzył ponad cztery miliony talarów. Sam Władysław Konopczyński stwierdził o drugim z ministrów: „doskonały samolub, groszorób, bez polotu i poczucia służby publicznej, uosobienie powszechnych zdolności i pospolitych przywar, pasożytował na dwóch społeczeństwach"13. Jednak jakby o nim źle nie mówić, trzeba przyznać, że doskonale obracał się w kręgach politycznych, co wpłynęło na upadek jego przeciwnika - Aleksandra Józefa Sułkowskiego. Niestety, autorowi nie udało się ustalić argumentów, jakich użyto przeciwko Sułkowskiemu, a które przyczyniły się w ostateczności do odsunięcia tego ministra od wielkiej polityki i dworu. Oczywiście wynika to ze złożoności problemu, który ciężko potwierdzić bezpośrednio w źródłach.

Niezwykle ciekawą kwestią, poruszoną słusznie w pracy, było rozdawnictwo Orderów Orła Białego. Order ten stanowił dla magnackiej arystokracji wielki zaszczyt, dlatego też zabiegali o niego wszyscy. W książce przedstawiono mechanizmy, jakie panowały przy pozyskiwaniu dla siebie tych jakże cennych odznaczeń, chociaż w habilitacji nie zostało bezpośrednio nazwane zabiegami korupcyjnymi. Sułkowski otrzymał ten order w 1735 roku i sam przyczynił się do przyznania go innym, zaprzyjaźnionym z nim magnatów. Dużo racji w tej tematyce ma Stanisław Roszak, który w swoich rozważaniach zastanawiał się, czy kawalerowie orderu stawali się depozytariuszami planów królewskich i wykonawcami jego polityki i na ile pozostawali twórcami oraz uczestnikami nowego obyczaju ${ }^{14}$. Niemniej jednak przyglądając się polityce rozdawnictwa tych odznaczeń, uwidacznia się symbol korupcji czasów saskich. Działania A. J. Sułkowskiego przedstawione tutaj są tego absolutnym dowodem.

Pewną małą szkodą dla podjętych badań było odsunięcie na drugi plan jego życia rodzinnego, zwłaszcza relacji, jakie łączyły go z żonami. Wiemy jednak z literatury, że jego potomstwo potrafiło, jak ojciec, zadbać

13 W. Konopczyński, Brühl (von) Henryk, „Polski Słownik Biograficzny” 1937, t. 3, s. 20 .

${ }^{14}$ S. Roszak, Geneza i rozwój Orderu Orta Biatego w czasach saskich, [w:] Między zachodem a wschodem. Studia ku czci profesora Jacka Staszewskiego, t. 2, red. J. Dumanowski, B. Dybaś, K. Mikulski, J. Porazinski i S. Roszak, Toruń 2003, s. 529. 
o własne interesy i majątek. Synowie, co ciekawe, byli również kontrowersyjnymi postaciami ${ }^{15}$. Opisując życiorys magnata epoki staropolskiej lub chociaż jego fragment, nie sposób nie wspomnieć o majątku. Z pracy wynika, że nie należał do wybitych polityków, ale był na pewno lepszym gospodarzem. Nie będzie błędem stwierdzenie, że interesował się w dużym stopniu rozwojem swoich dóbr, co więcej, wydawał liczne przywileje i regulacje mające na celu usprawnić ich funkcjonowanie. Dzięki wsparciu króla uzyskał szereg majątków, ale dzięki swojej gospodarności umocnił się w gronie najbogatszych magnatów pierwszej połowy osiemnastego wieku. Dbał o sukcesywne powiększanie swojego portfela, nawet będąc na politycznym marginesie. Oprócz dóbr posiadanych w Warszawie lub Saksonii miał wsie na pograniczu śląsko-wielkopolskim. Zdarzało się, że nabyte miejscowości, które były w nie najlepszym stanie, odbudowywał, tworząc $\mathrm{z}$ nich dochodowe gospodarstwa. Utrzymywał kontakty z dawnymi stronnikami z czasów, gdy był ministrem. Przykładem jest wspomniany kilkukrotnie wcześniej J. A. Czapski, któremu sprzedał Bielawki pod Warszawą.

Sułkowski oprócz bycia dobrym gospodarzem był również hojnym mecenasem sztuki. Bardzo lubił włoską architekturę i sztukę, pomimo tego, że zatrudniał przede wszystkim niemieckich architektów oraz artystów. Stał się zresztą fundatorem kościołów w Kłodzie, Rydzynie cz Sicinach ${ }^{16}$. Dbał, jak na lidera rodziny przystało, o potomstwo, by te dostatnio mogło rozpocząć dorosłe życie. Z dwóch małżeństw (z Marią Franciszką Stein i Aleksandrą Przebendowska) miał siedmioro dzieci (czterech synów i dwie córki). Im to właśnie pozostawił duży majątek, prawdopodobnie nieobarczony długami. Podwaliny pod te zagadnienia podłożył wcześniej Michał Zwierzykowski, który zauważył, że jego szczególna aktywność przypadła na okres 1736 roku i późniejsze lata ${ }^{17}$. Częściowo opisał je również autor niniejszej rozprawy w biogramie poświęconym tej postaci zamieszczonym

\footnotetext{
15 Wspomina o tym H. Palkij, op. cit., s. 14.

16 Ibidem, s. 19.

${ }_{17}$ M. Zwierzykowski, $Z$ badań nad gospodarczymi podstawami mecenatu Aleksandra Józefa Sutkowskiego, [w:] Sutkowscy-życie i dzieto..., s. 43-59.
} 
w Polskim Słowniku Biograficznych ${ }^{18}$. W nieco mniejszym stopniu zagadnienia te zostały omówione w recenzowanej biografii.

Rzeczą niezwykle istotną dla rozważań nad tą postacią jest kwestia przejmowania dóbr po Stanisławie Leszczyńskim, który po opuszczeniu Królewca udał się do Francji, gdzie przebywał już do końca życia. Otóż największe dobra po byłym królu znajdowały się w Wielkopolsce i były łakomym kąskiem dla wielu. O przebiegu prac nad przejmowaniem dóbr informował na bieżąco Sułkowskiego Jan Ansgary Czapski. Najbardziej okazałym nabyciem było Leszno, które uzyskał ostatecznie w marcu 1738 roku. Jak słusznie podkreśla Adam Perłakowski, nabycie majątków po Leszczyńskim nie zostało dobrze odebrane przez szlachtę. Kwestiami, o które toczyły się największe spory, był fakt zadłużenia i możliwości uregulowań poszczególnych należności przez byłego monarchę. Dotyczyło to siedmiu miast i dwustu wsi, zamieszkałych przez ok. dwadzieścia tysięcy ludności. Pewnym brakiem jest pominięcie w tym rozdziale udziału wojewody pomorskiego Piotra Jana Czapskiego, który jako zagorzały zwolennik Leszczyńskiego był współodpowiedzialny za życia za uregulowanie spraw majątkowym po byłym monarsze.

Ostatnia część książki (Teraz żadnej dać nie moge rezolucyji, będąc oddalony a la tere JKM PNM. Dymysja i jej konsekwencje) stanowi nie tylko omówienie opinii, jakie pojawiły się w historiografii polskiej i niemieckiej na temat przyczyn odwołania Sułkowskiego z pełnionych dotychczas funkcji, ale także przedstawia dalsze jego losy. Uwidacznia się duża krytyka, jaka spadła na niedawnego faworyta królewskiego. Liczba paszkwili, która pojawiła się w 1738 roku, potwierdza powyższe stwierdzenie. Niestety, najważniejsze pytanie odnoszące się do argumentów Brühla, które przyczyniły się do „upadku” pierwszego ministra, pozostaje bez odpowiedzi. Pracę kończą uwagi (s. 253-261), które właściwie stanowią krótką refleksję na temat roli Sułkowskiego na dworze Augusta III i jego konflikcie z oponentami. Pewną szkodą jest nienawiązanie do karier innych Sułkowskich. Rodzina,

${ }^{18} \mathrm{O}$ działalności gospodarczej, jak i mecenacie wspomina również A. Perłakowski w biogramie poświęconym A. J. Sułkowskiemu. Zob. A. Perłakowski, M. Zwierzykowski, Sutkowski Aleksander Józef. H. Sulima, „Polski Słownik Biograficzny” 2008, t. 45/4, z. 187, s. 519-528. 
a dokładniej potomstwo Aleksandra Józefa, również odgrywała znaczącą rolę w Rzeczypospolitej. Ten stan rzeczy był spowodowany podwalinami, jakie zbudował były faworyt króla Augusta III.

Prace wzbogaca aneks w formie tabelarycznej (s. 261-278), przedstawiający zestawienie umów z kontrasygnatą A. J. Sułkowskiego i H. von Brühla, zawartych ze skarbem podróżnym w latach 1734-1736. Jest to ciekawe uzupełnienie książki, chociażby z tego względu, że pokazuje, na co przeznaczane były pieniądze ze skarbu państwa.

$\mathrm{Na}$ pewno cieszy, że biografia tego polityka powstała, chociażby z powodu wyjaśnienia wielu niejasności oraz przybliżeniu stosunków Sułkowskiego z Brühlem. Wielką szkodą dla pracy jest niewątpliwie brak kwerendy w Archiv Wniesznoj Politiki Rossijskoj Imperii, o którym wspomina autor: nie udato mi sie przeprowadzić poszukiwań. Kierownictwo placówki poinformowato mnie listownie, że nie znajdę $w$ tamtejszym zasobie niczego, co mogtoby mi sie przydać w pracy naukowej, związanej z dziejami unii polsko-saskiej ${ }^{19}$. Myślę, że biorąc pod uwagę fakt pewnej „niegościnności”, należy w przyszłości odszukać materiały, które będą dalej czytelnikom przybliżać tą postać. Będąc przy temacie archiwów, nie sposób ominąć tematu źródeł znajdujących się w archiwum w Mińsku, które również w swoich zasobach posiada materiały dotyczące wydarzeń z lat trzydziestych XVIII wieku. Przede wszystkim chodzi o źródła z archiwaliów radziwiłłowskich, niezwykle ważnych dla badaczy zajmujących się życiorysami polskich i litewskich arystokratów XVI-XVIII wieku. Warte pochwalenia jest również przeprowadzenie kwerendy w Riksarkivet w Sztokholnie. Praca ta jest kolejnym dowodem na to, że polscy historycy zajmujący się epoką nowożytną powinni zwracać na tamtejsze zasoby większą uwagę. Cieszy również fakt, że autor wykorzystał niezwykle ciekawą korespondencje znajdującą się w zbiorach Biblioteki Poznańskiego Towarzystwa Przyjaciół Nauk. Oprócz wyżej wymienionych instytucji, autor przeprowadził kwerendy w wielu innych zagranicznych archiwach i bibliotekach, w tym m.in. w Archives Diplomatiques w la Courneve, Archivio Segreto w Watykanie czy w Sächsisches Hauptstaatsarchiv w Dreźnie.

${ }^{19}$ Cytat ze wstępu omawianej pracy, s. 15. 
Biografia pióra Adama Perłakowskiego zarówno pod względem wykorzystanej literatury przedmiotu, jak i podmiotu jest imponująca. Zastanawiać może fakt, czy rzeczywiście należało spisy urzędników zamieszczać w części poświęconej dla źródeł drukowanych. Być może należałoby je przenieść do części opracowań. Niemniej jednak w pracy zostały wykorzystane tak starsze, jak i nowsze pozycje omawiające życie polityczne czasów saskich. Również skorzystanie z prac wielu zagranicznych autorów miało wpływ na dokonanie wielu nowych ustaleń. Niekiedy jednak w bibliografii można znaleźć małe błędy, a dotyczą one ram ułożenia alfabetycznego wybranych pozycji. Przykładem są tu prace Tomasza Ciesielskiego czy Jerzego Dygdały (s. 293-294), które nie zostały ułożone w porządku alfabetycznym.

Reasumując, ustalenia, jakich dokonał Adam Perłakowski, są niezwykle ciekawe z wielorakich względów. Po pierwsze, w pracy zostały obalone pewne stare sądy na temat tej postaci. Sam jej życiorys został niezwykle szczegółowo uzupełniony o nowe fakty. Najciekawsze, jak można się domyślać, jest opisanie upadku Sułkowskiego, do którego niechybnie przyczynił się minister Henryk Brühl. Ukazana tu została wewnętrzna rywalizacja między urzędnikami, którzy własne kariery przedkładali nad dobro ogółu. Co więcej, recenzowana książka przedstawia mechanizmy działania dworu, które często pochłonięte było wewnętrznymi antagonizmami. Po drugie, praca świetnie przedstawia zawiłe tło polityczne, w jakiej znalazła się nie tylko Rzeczpospolita, ale także Saksonia w pierwszej połowie XVIII wieku. Po trzecie zaś, praca przybliża czytelnikom postać, która w ciągu kilku lat z przeciętnego, mało znaczącego szlachcica staje się potężnym i bardzo wpływowym magnatem nie tylko na obszarze Rzeczypospolitej.

Mikotaj Tomaszewski 


\section{KRONIKA NAUKOWA}

Klio. Czasopismo poświęcone dziejom Polski i powszechnym PL ISSN 1643-8191, t. 35 (4)/2015, s. 237-249

Konferencja „Origines et mutationes 2" Exchange and power around the Baltic Sea Region up to Industrial Age, Pruszcz Gdański, 3-5 IX 2015

W dniach 3-5 IX 2015 roku na terenie Międzynarodowego Bałtyckiego Parku Kulturowego Faktoria w Pruszczu Gdańskim odbyła się druga edycja konferencji „Origines et mutationes 2”. Została ona zorganizowana przez Wydziały: Historyczny oraz Prawa i Administracji Uniwersytetu Gdańskiego i Towarzystwo Naukowe „Pruthenia” przy wsparciu burmistrza Pruszcza Gdańskiego, Janusza Wróbla. Obradom patronował rektor Uniwersytetu Gdańskiego prof. Bernard Lammek oraz władze samorządowe i wojewódzkie. W czasie konferencji wygłoszono 26 referatów, których autorzy odnosili się do tegorocznego hasła przewodniego konferencji „exchange and power” (wymiana i władza).

Konferencję otworzyły powitania wygłoszone przez prorektora Uniwersytetu Gdańskiego, prof. UG Józefa A. Włodarskiego oraz przedstawicieli samorządu, burmistrza Pruszcza Gdańskiego Janusza Wróbla oraz starosty gdańskiego Stefana Skoniecznego. Szczególnie podkreślali oni, że w organizację wydarzenia udało się włączyć wiele instytucji, a także zaprosić do udziału w niej badaczy nie tylko z Polski, ale również z Niemiec, Skandynawii, Litwy i Wielkiej Brytanii. 